\title{
ANALYSIS OF COMPANY CAPABILITY, SUPPLY CHAIN MANAGEMENT OF COMPETITIVE ADVANTAGE, AND COMPANY PERFORMANCE
}

\author{
Nuraini $^{1}$ \\ Universitas Labuhanbatu, Labuhanbatu, Indonesia \\ nuraini28111998@gmail.com \\ Sumitro Sarkum² \\ Universitas Labuhanbatu, Labuhanbatu, Indonesia \\ sumitro@ulb.ac.id \\ Abdul Halim ${ }^{3}$ \\ Universitas Labuhanbatu, Labuhanbatu, Indonesia \\ abdulhalimpsr89@gmail.com
}

\begin{abstract}
The main purpose of the study is to determine the situation that affects the independent variables like the company's ability, supply chain management practices, supply chain responsiveness, and supply chain strategy regarding competitive advantage which is used as the dependent variable. The conclusion of this test shows that the company's performance can develop quality with competitive advantages and supply chain management practices that are met. Likewise, with the capabilities of the company, supply chain responsiveness and supply chain strategies have a positive effect so that companies can increase their competitive advantage. To be able to advance competitive advantage, companies must pay attention to and know the weaknesses that can become problems, it is necessary to have strengths by implementing supply chain management to maintain the company's competitive advantage.
\end{abstract}

Keywords: Excellence, Performance, Supply Chain Management 


\section{INTRODUCTION}

Some developing countries such as Indonesia can not only depend on large companies but also need the participation of MSMEs which have an important position also for the development and progress of income, because they contribute to the development of gross domestic product and the provision of jobs. (Lestari et al., 2019). Based on the Central Bureau of Statistics in 2015 the number of small industries in Labuhanbatu Regency was 60 industries. This figure continues to fluctuate from year to year until in 2019 the number of industries in Labuhanbatu Regency amounted to 65 industries. The small industries are spread across the North Rantau sub-district as many as 17 industries, then Rantau Selatan as many as 14 industries. There are 19 large/medium industrial companies and the most are in the District of Bilah Hulu as many as 5 companies and one of them is the Company "Efforts to Increase Prosperous Family Income" or UPPKS Ananda Jaya with the product type Onion Cake.

The company managed to gain a competitive advantage because of the maximum supply chain management. The industry performs very superior performance against competitors, this happens because of supply chain management that can minimize the totality of tariffs in increasing and realizing customer desires. Supply chain management is all the parts involved, in a direct but indirect way to realize the wishes of customers. All participating parties are not only part of the manufacturer or seller, and also include distributors, documentation sites, and customers. The implementation of supply chain management is required in the industry because it will advance the company's competitive advantage on company performance. The application of supply chain management practices is the main role of working in product procurement and this is what is required for companies to advance the competitive advantage of the industry and can have an impact on company performance. Competitive advantage is needed for the industry to be able to maintain its competitive state in serving its competitors to be able to advance the company's performance to achieve its goals (Ilmiyati \& Munawaroh, 2016).

Thus, a phenomenon appears in the company, namely it is important to design a discussion of stock supply to strengthen the supply chain management can help the strategies made by the industry, it is necessary to have a supply chain strategy to improve the company's operations so that they can compete and still have a position in the market. The findings in this analysis aim to understand the impact on supply chain management regarding the competitive advantage and company performance, the findings of this analysis are the positive impact of 
SCM on competitive advantage. (Maddeppungeng \& Kusuma, 2019). Meanwhile, according to (Yun et al., 2020) supply chain integration and competitive advantage show a negative impact. UPPKS, including MSMEs, is a segment of the development of the economic and social divisions, so it must conduct optimal supply chain management to develop its achievements. The need for citing this discussion is so that the owners are able to make UPPKS Ananda Jaya in Labuhanbatu Regency able to persist in keeping up with increasingly fierce business competition, required through the development of supply chain management and competitive advantage that is implemented to advance the way of working and then can develop the continuation of the company UPPKS Ananda Jaya in Labuhanbatu Regency. Conducted research on UPPKS Ananda Jaya to be able to solve problems in the company and help provide solutions so that the company can maintain its position in the market.

Sourced from the introduction above and the need considering the influence of strategy and supply chain management on competitive advantage, competitiveness, and performance of the UPPKS Ananda Jaya company in Labuhanbatu Regency, this research problem arises, including: 1) What is the impact of the company's ability on competitive advantage?; 2) What is the impact of supply chain management practices on competitive advantage?; 3) What is the impact of supply chain responsiveness on competitive advantage?; 4) What is the impact of the supply chain strategy on competitive advantage?; 5) What is the impact of supply chain management practices on company performance?; 6) What is the impact of competitive advantage on company performance?

\section{REVIEW OF LITERATURE}

\section{Company Capability}

Corporate competitiveness is the ability of a company to develop and develop a variety of strategies that can put it in a strategic position and are more useful when compared to other companies. (Pahlavi, 2020). Companies are expected to form competitive forces to provide economic quality and to be able to compete with other companies or industries. One aspect that states that a business can have extraordinary competitive power can be considered through the integration performance of each component of its supply chain (Deswati, Rismutia Hayu, 2020). Regarding the variables of the instrument, the company's ability is the ability to reduce costs, service capabilities, market interpretation skills, relationship management capabilities, integration capabilities, and technological capabilities. 


\section{Supply Chain Management Practices}

GSCM practices can lead to the implementation of management principles for the community and all arrays of supply activities, such as project design, supply, manufacture, and manufacture, (Brilliana et al, 2020). The practice of supply chain management is defined as "part of an activity carried out by an organization by positively marketing the management of supply" (Li et al., 2015). The author further emphasizes that the practice of supply chain management is proposed to be a multi-dimensional concept, which has been seen as a comprehensive concept (Rachmarwi, 2018). Regarding the instruments used, the variables of supply chain management practice are customer relations, close supplier relationships, various information, logistics supply chain integration, strategic locations.

\section{Supply Chain Responsiveness}

The supply of goods (supply chain) is a basic part of a production and the services contained in it include a series, activities, facilities, and work that are passed to create and deliver goods to consumers as the final user. A series that includes supply chain activities such as raw materials, manufacturing methods, delivery of goods to the hands of customers (Kasmari \& Indriyaningrum, 2020). The supply chain is a network of companies that are simultaneously in charge of making a product so that it offers it to customers. And these companies include suppliers, factories, distributors, shops, or retailers along with the provision of services as support for the company. So, the supply chain has three parts that must be implemented. The first part is the flow of material, money, and information that can flow upstream to downstream or downstream to upstream(Brilliana et al., 2020). The external influence of SCM Supply Chain Management on the company increases the visibility of demand among the entire supply chain so that each company in the supply chain can more efficiently and effectively plan and run operations (Madeppungeng et al., 2020). Regarding the instruments used from the supply chain response power variables are operating system responsiveness, logistics process responsiveness, supplier network responsiveness, information exchange, management competence and supply flexibility.

\section{Supply Chain Strategy}

Strategy is an activity in a company to control wealth for a long time. And has a multifunctional and multidimensional influence so that it requires estimation, of internal and external factors that will be encountered. Strategy shares knowledge about how, where, and 
when to compete, and with whom to compete, and the objectives of the competition(Lobwaer, 2018). Strategic planning is an activity carried out to build a strategy that can assist in achieving the goals/goals of the industry. There are five general steps in the strategic planning process; goals/goal setting, situation analysis, alternative considerations, implementation, and evaluation. Strategic planning consists of the planning processes carried out in the company in developing strategies that might contribute to performance (Lasminiasih, Rooswhan Budhi Utomo, 2018). SCM strategy is needed for companies to achieve attractive objectives contained in the company's strategy. Updates on the supply chain strategy design can provide a competitive advantage in every company(Arifianti et al., 2019). According to (Mohamad \& Niode, 2020)Strategy is a tool used in achieving the company's goals for a long time, along with the importance of providing resources. There are instruments of supply chain strategy variables that are a competitive advantage, demand flexibility, process capability, process time limit, strategic risk.

\section{Competitive Advantage}

Peter conveyed that actually, competitive advantage is a thought that meets competence and the most important thing is to create competitive advantage and means it is used as a tool in achieving their respective goals. Rather it is a competitive advantage as the strength of a building to be able to advance results for customers then compared to competitors to have a productive state, and the challenge is to uphold each priority in an achievement. This information reveals that competitive advantage is obtained when implementing a strategy so as not to create value simultaneously from other existing actors and hidden actors (Yun et al., 2020). In the everincreasing competition, companies should have very strong competitiveness so that they can always compete against other companies and the main thing is similar companies. Each company certainly has a variety of strategies to gain a competitive advantage. The ability to compete in the strength of a business by providing good quality of its products compared to its competitors and that quality does provide benefits to consumers. Competitive advantage is also an advantage over competitors because it gets fewer quality offerings even though it provides more profits. After all, the costs are high(Riany, 2020). Following from Crown Dirgantoro's competitiveness is the quality growth a company can make in its purchase. Agustina Sri Wahyadi conveyed the meaning of competitive advantage is to allow a company to get a superior profit compared to the average profit earned by competitors in the industry. (Mohamad \& Niode, 2020). Therefore, the 
instruments used from the competitive advantage variables are cost, quality, flexibility, innovation, time to market.

\section{Company performance}

The company's performance describes the arrangement of the implementation orientation of activity to get the mission and vision goals of the company that have been formed in a strategy-making of the company. The company's performance can be measured through profitability, investment-taking stage (RIO), company's basic income, development, change, and asset collection stage (ROA/ROE). Therefore, the company's performance calculated through ROA/ROE is part of the company's operational performance. Meanwhile, profitability is intended to understand the company's capabilities to provide benefits to find out how far the company is operating practically and effectively(Supriyato \& Rahmasari, 2020). The company's performance proves administrative skills when utilizing capital to carry out activities to gain profits. The stronger the fluctuations in management's ability to gain profits by proving a profit shift, the stronger will be. This situation controls investors to anticipate the consequences and profits on investment so that the company gains the trust of investors. Because of this, managers are motivated to carry out profit management, so that the profits conveyed do not always increase to be able to gain the trust of investors(Chandra et al., 2021). Company performance is a condition that is necessary to draw important conclusions, both internally and externally. The company's performance shows the strength of the industry to earn a profit through assets, equity, or debt. Company performance is a result obtained from the company's performance. The performance of the company becomes a benchmark as a whole to see the success of the company or organization over a certain time by utilizing, managing, and controlling its resources. (Qinthara et al., 2020). Therefore, the instruments used from the company's performance variables are financial performance, marketing performance, operational performance, supply performance, customer relations, and operational costs.

\section{Hypothesis Development}

\section{The relationship of the company's ability to competitive advantage}

In connection with the results of research conducted by Rani Noviani (2019), namely the image of the company has a good and significant impact on competitive advantage, which can be interpreted as the better the service level of J\&T Express employees, the better the J\&T Express company image itself and with a better service system management. always put the customer 
first, the company's good image will always be known by the public and competitive advantage will emerge (Daily, 2020). Therefore, human resources who master and have entrepreneurial competence will have the quality to serve the internal and external components of the company and then can control these components to create strategies that are useful for the company to get a transition that makes differentiation compared to competitors Then entrepreneurial adjustment can have a significant impact on the strength of competitors(Lestari et al., 2019). Some of the results of these researchers, the hypothesis is as follows:

Hypothesis 1: The company's ability to have a positive impact regarding competitive advantage The relationship of supply chain management practices to competitive advantage

The positive path coefficient means that the relationship between Green supply chain management means that the company's competitiveness is in the same direction. This means that the better the implementation of green supply chain management, the company's competitiveness will increase. The opinion from the previous analysis that the application of green supply chain management has a significant impact on competitive advantage, that the application of supply chain management at a higher level plays an important role in increasing the company's competitive advantage (Jumady, 2020). Many previous studies have discussed the impact of supply chain management practices on competitive advantage and various pre-analyses were found to monitor the influence of competitors' advantages and industry performance and vice versa. This shows that there is a bond in supply chain management practices through competitive advantage and industrial achievement, with the development of this competitiveness being able to create a better situation to develop industrial achievement (Nurdianti et al., 2017). Then, it can be concluded the relationship as follows:

Hypothesis 2: Supply chain management practices have a positive impact on competitive advantage

\section{The relationship of supply chain responsiveness to competitive advantage}

Supply chain responsiveness has a positive impact on the creation of a company's competitive advantage (Sukati et a, 2011) in this study, detecting a positive impact between operational system responsiveness instruments, logistics process responsiveness, and supplier network responsiveness has a positive connection to competitive advantage. . Through the implementation of an effective response, the company continues to strive against competitors on the quality of tariff advantages, when entering the market, and demands from customers. 
Responsive procurement techniques can also keep the company ahead. (Kurniawan et al., 2018). The company's advantages can meet the shift in the number of consumer demands so that it can advance the company's competitive advantage through the aspect of product supply. The better the quality of a company's supply chain responsiveness, the more positive a company's competitive advantage will be (Kurniawan et al., 2018). From some of these studies, there is a relationship as follows:

Hypothesis 3: The responsiveness of the supply chain has a positive impact on competitive advantage

\section{The relationship of competitive advantage to company performance.}

The positive path coefficient means that high competitiveness can help the development of the company's performance and the better the competitiveness, the stronger the company's performance. The findings of these researchers can prove some competitive advantage theories by Porter that competitors are the center of the company's success and defeat, as well as determine the activities of the company (Jumady, 2020). Competitive Advantage has a good and significant impact on the company's performance. Low costs, higher value, agility in transporting and innovating goods on an ongoing basis will increase sales of goods and can control the trade. These are parameters for the company in meeting the achievement of company performance that focuses on its financial goals (Ilmiyati \& Munawaroh, 2016). Competitive advantage is a way to get to the final goal of the company, namely developing company performance. Thus, that it can explain a hypothesis about competitive advantage having a positive effect on the performance of input companies to be able to reach the company's ultimate goal, namely advancing company performance (Nelly \& Azhar, 2016). From the results of the study, it can be concluded a relationship as follows:

Hypothesis 4: competitive advantage has a positive impact on company performance

\section{The relationship of supply chain management practices to company performance}

In a study with the theme the impact of supply chain management practices on competitive advantage and organization performance, it was determined that supply chain management practices have a significant relationship with the achievement of company performance. With supply chain management practices, the company benefits in terms of manufacturing competence which has the influence and advantages of cooperation which is the key to its supply chain (Kurniawan et al., 2018). Variables from supply chain management 
practices, namely strategic partnership relationships, consumer bonds, report sharing, and resignations have a positive effect on competitive advantage and company performance (Sanjaya et al., 2016). From the conclusion of the analysis, a relationship is obtained as follows:

Hypothesis 5: supply chain management practices positive impact on company performance

\section{The relationship of supply chain strategy to competitive advantage}

One strategy that can be used to create a competitive advantage in SMEs is a strategy in the supply chain. Integrating supply chain, market, and product strategies have proven to be achieved in increasing the development of SME market and product innovations. To increase the competitive advantage in the supply chain, it is necessary to study the benchmarks that affect the competitiveness of the supply chain (Arsiwi \& Adi, 2020). Researchers Regina Suharto and Devie on "Analysis of the flow of supply chain management competitive advantage and company performance". The conclusion of this analysis is useful to understand the relationship of supply chain management to competitive advantage and company performance, empirical survey as a research method, distributing questionnaires, interviews, and PLS programs, the findings in this study are the positive influence between SCM on competitive advantage (Maddeppungeng \& Kusuma, 2019). Based on the results of the study, it can be concluded a relationship as follows:

Hypothesis 6: Supply chain strategy has a positive impact regarding competitive advantage

Figure 1

\section{Research Framework}

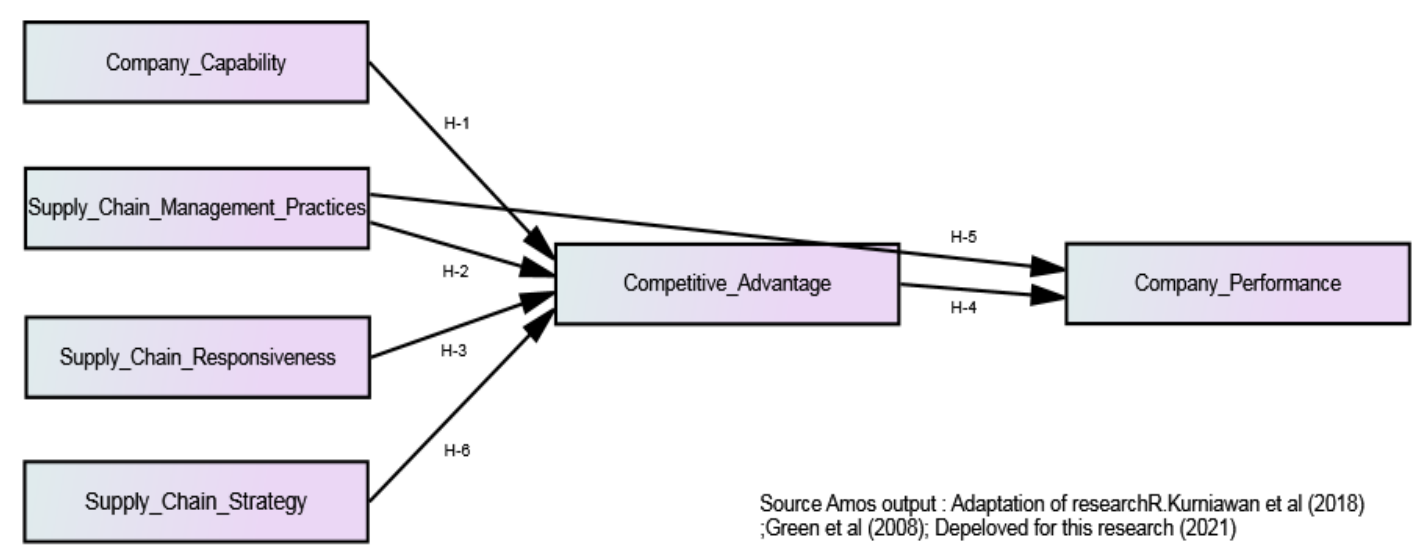




\section{RESEARCH METHOD}

The phenomenon in this analysis is the distributor of UPPKS Ananda Jaya, which is located in Dusun Jawa A. Desa Kampung Dalam, Kec. District Upstream Bar. Labuhanbatu. This qualitative researcher uses a non-probability sampling method and uses accidental sampling technique. Because population sampling is done by chance using a questionnaire, according to Hair et. al (2014) with a total sample of at least 5 to 10 times the total instrument. Hair et. al (2014) provide an opinion on the number of samples between 100-200 respondents. The sample used in this analysis amounted to $5 \times 30$ indicators, namely 150 respondents were able to represent the entire population. The accumulation of respondents cannot be carried out directly due to the location between customers who are far apart so that it takes a long time. Statistical accumulation is carried out online, by distributing a questionnaire link using a Google form. This study uses the AMOS software analysis tool for testing research hypotheses. Before conducting the research, the instrument was tested first using the SPSS Statistics 20 technique as follows:

Table 1

Variable Validity Test Results

\begin{tabular}{|c|c|c|c|c|}
\hline Variable & Instrument Items & $\begin{array}{l}\text { Corrected } \\
\text { Item-Total } \\
\text { Correlation }\end{array}$ & $\begin{array}{l}\text { Cronbach } \\
\text { 's Alpha }\end{array}$ & Reference \\
\hline \multirow{4}{*}{$\begin{array}{l}\text { Enterprise } \\
\text { capability (X-1) }\end{array}$} & X1.1 Keeping costs down & 0.736 & \multirow[t]{4}{*}{0.850} & \multirow{4}{*}{$\begin{array}{l}\text { (Kurniawan et } \\
\text { al., 2018) }\end{array}$} \\
\hline & X1.2 Service & 0.883 & & \\
\hline & X1.3 Interpreting the market & 0.827 & & \\
\hline & X1.4 Integration and technology & 0.755 & & \\
\hline \multirow{4}{*}{$\begin{array}{l}\text { Supply Chain } \\
\text { Management } \\
\text { Practices (X-2) }\end{array}$} & X2.1 Customer relationship & 0.624 & \multirow[t]{4}{*}{0.739} & \multirow{4}{*}{$\begin{array}{l}\text { (Rachmarwi, } \\
\text { 2018) }\end{array}$} \\
\hline & X2.2 Close supplier relationship & 0.669 & & \\
\hline & X2.3 Information sharing & 0.612 & & \\
\hline & X2.4 Integration and technology & 0.631 & & \\
\hline \multirow{3}{*}{$\begin{array}{l}\text { Supply Chain } \\
\text { Responsiveness } \\
(\mathrm{X}-3)\end{array}$} & X3.1 Operating system & 0.602 & \multirow[t]{3}{*}{0.713} & \multirow{3}{*}{$\begin{array}{l}\text { (Kurniawan et } \\
\text { al., 2018) }\end{array}$} \\
\hline & X3.2 Logistics process & 0.779 & & \\
\hline & X3.3 Supplier network & 0.527 & & \\
\hline \multirow{4}{*}{$\begin{array}{l}\text { Supply Chain } \\
\text { Strategy (X-4) }\end{array}$} & X4.1 Competitive advantage & 0.644 & \multirow[t]{4}{*}{0.750} & \multirow{4}{*}{$\begin{array}{l}\text { (Arifianti et } \\
\text { al., 2019) }\end{array}$} \\
\hline & X4.2 Flexibility of requests & 0.535 & & \\
\hline & X4.3 Process capability & 0.596 & & \\
\hline & X4.4 Strategy risk & 0.743 & & \\
\hline \multirow{5}{*}{$\begin{array}{l}\text { Competitive } \\
\text { Advantage (Y-1) }\end{array}$} & Y1.1 Cost & 0.809 & \multirow[t]{5}{*}{0.930} & \multirow{5}{*}{$\begin{array}{l}\text { (Edy Jumady, } \\
\text { 2020) }\end{array}$} \\
\hline & Y1.2 Quality & 0.791 & & \\
\hline & Y1.3 Flexibility & 0.768 & & \\
\hline & Y1.4 Innovation & 0.803 & & \\
\hline & Y1.5 Time to market & 0.923 & & \\
\hline Company & Y2.1 Financial performance & 0.671 & 0.702 & (Kurniawan et \\
\hline
\end{tabular}




\begin{tabular}{|c|c|c|c|}
\hline \multirow{3}{*}{$\begin{array}{l}\text { Performance (Y- } \\
\text { 2) }\end{array}$} & Y2.2 Marketing performance & 0.779 & \multirow[t]{3}{*}{ al., 2018) } \\
\hline & Y2.3 Operational performance & 0.480 & \\
\hline & Y2.4 Provisioning performance & 0.587 & \\
\hline
\end{tabular}

Source: SPSS data processing results, 2021 (Research processed)

Based on Table 1, validity and reliability tests were carried out, a measurement scale was said to be valid or invalid an indicator if the Corrected item-total Correlation value was more than 0.361. To understand the reliability of the research variables using Cronbach's Alpha a minimum of 0.70 (Nurkamil et al., 2020). Before testing, there were 30 indicators, so from all the variables that 6 indicator items were recognized as invalid because the number of Corrected item-total Correlation was lower than 0.361 while the others were valid because the number of Corrected item-total Correlation was very high than 0.361 applied. Then a construct or variable is said to be reliable if the Cronbach Alpha is greater than 0.70. From the conclusions in Table 1, the reliability proves that the Cronbach Alpha value is greater than 0.70 because it is declared good or reliable.

\section{RESULTS AND DISCUSSION}

From the results of the research above, there is a path analysis model that has been tested for validity and reliability, namely as follows:

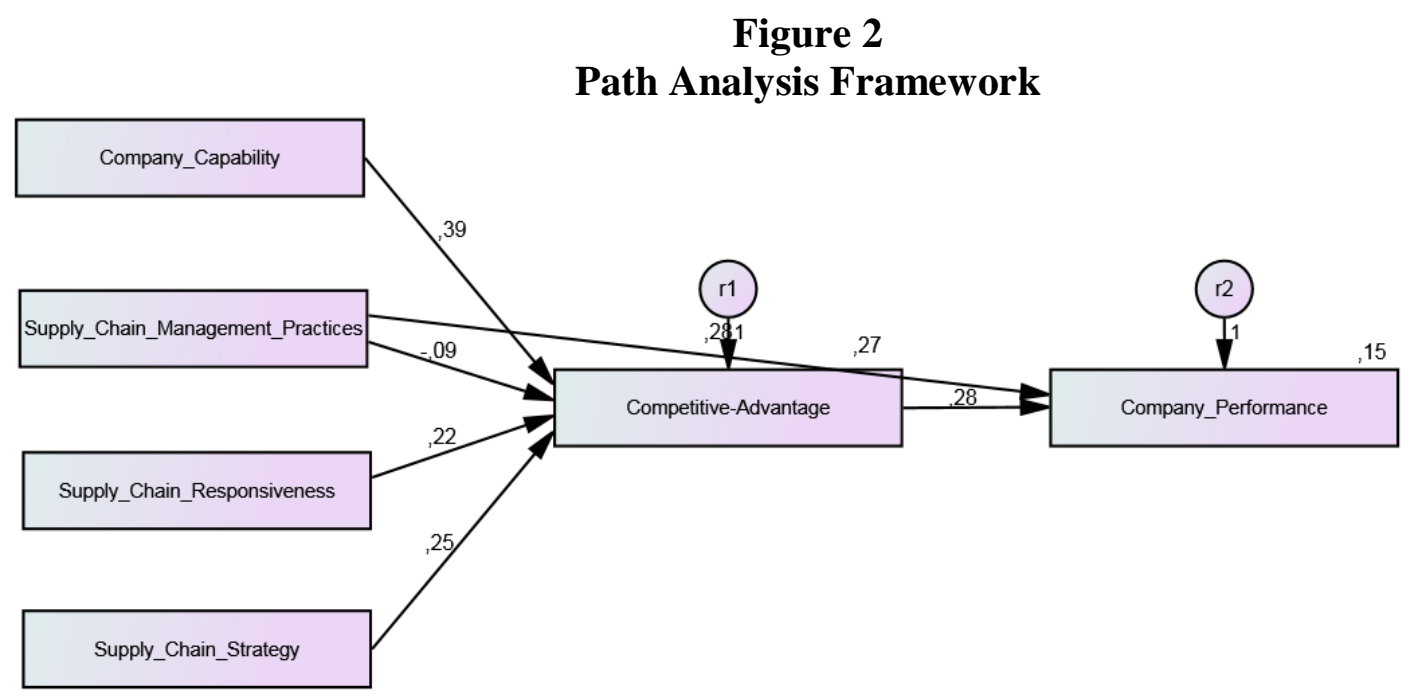

Source: Amos Output, 2021 
Table 2

Regression Weights:

\begin{tabular}{|c|c|c|c|c|c|c|}
\hline & & & Estimate & SE & $\mathrm{CR}$ & $\mathrm{P}$ \\
\hline Advantage_Power_Competitive & $<--$ & Company_Capabilities & ,448 &, 123 & 3,630 & $* * *$ \\
\hline Advantage_Power_Competitive & $<---$ & Practice_Management_Supply_Chain &,- 097 &, 127 &,- 763 & ,446 \\
\hline Advantage_Power_Competitive & $<---$ & Power_Response_Supply_Chain & ,298 & , 104 & 2,867 & ,004 \\
\hline Advantage_Power_Competitive & $<---$ & Strategy_Supply_Chain &, 200 &, 065 & 3.070 & ,002 \\
\hline Company performance & $<---$ & Practice_Management_Supply_Chain & ,382 &, 112 & 3,420 & $* * *$ \\
\hline Company performance & $<---$ & Advantage_Power_Competitive & ,363 &, 103 & 3,519 & $* * *$ \\
\hline
\end{tabular}

Amos Output Source, 2021

Based on Table 2 above, it can be obtained that the test results between variables with the number of probabilities below the number 0.05 can be declared significant, as well as if the number of probabilities exceeds the value of the number 0.05 so that it is declared insignificant. And it was found that one variable was not significant because it had a probability value of 0.446. After all, the value obtained was more than 0.05. Further explanation is as follows:

\section{The influence of company capabilities on competitive advantage}

Dissertation examination 1 of the company's ability to competitive advantage has a direct and significant effect by proving the conclusion of the calculation contained in the CR value of 3.630 and the probability value of 0.000 where the result is lower than the value of 0.05 , and this situation indicates that the company's ability has a positive influence. to competitive advantage, therefore H-1 was approved. Based on(Kurniawan et al., 2018) informing the company's ability to have a significant positive impact on competitive advantage, which means the company's ability to work hard can develop a competitive advantage at UPPKS Ananda Jaya.

\section{Effect of supply chain management practices on competitive advantage}

Dissertation examination of 2 supply chain management practices on competitive advantage has no significant effect by showing the conclusion of the calculation contained in the CR value of -736 and the probability value of 0.446 and this value is greater than the value of 0.05, hereby proves that supply chain management practices do not have a positive effect on competitive advantage, therefore H-2 is not approved. This can happen because it can be seen from the experience of the respondent that it is only 1-3 years, which means that the respondent does not have experience in business and this can also be strengthened. The conclusion in this 
analysis proves that good supply chain management practices cannot develop a competitive advantage because the weakness is that supply chain management practices are focused on the company's performance (Rachmarwi, 2018).

\section{The effect of supply chain responsiveness on competitive advantage}

Examination of the dissertation 3 supply chain responsiveness to competitive advantage has a significant effect by proving the calculation conclusions contained in the CR results are 2.867 and the probability value is 0.004 where the recorded number is lower than 0.05 , this condition shows that supply chain responsiveness has an impact both regarding competitive advantage, therefore H-3 was approved. Another finding, Al Hawajreh et al, (2014) suggests that supply chain responsiveness has a significant positive effect on competitive advantage. This means a good supply chain responsiveness can develop a competitive advantage.

\section{The effect of competitive advantage on company performance}

Dissertation examination of 4 competitive advantage on company performance has a direct and significant effect by proving the conclusion of the calculation contained in the $\mathrm{CR}$ value of 3.519 and the probability value of 0.000 which is a very low number than 0.05 , this condition reveals that competitive advantage has a good effect on company performance, because of that $\mathrm{H}-4$ was approved. Thus, the higher the competitiveness, the higher the company's performance. The findings of this study can prove with the competitive advantage theory by Porter that competition is the meaning of an industry's success and defeat, as well as determine the accuracy of the activities of the industry that can help the operational performance of the industry (Edy Jumady, 2020)

\section{Effect of supply chain management practices on company performance}

Examination of the dissertation of 5 supply chain management practices on company performance has a direct and significant effect by explaining the conclusions of the calculations contained in the CR value of 3,420 and the probability value of 0.000 where the lift has no value so it is lower than 0.05 , this condition proves that supply chain management practices have a positive impact on company performance, therefore H-5 was approved. Based on the analysis, it can be proven that supply chain management practices can maximize the company's performance at UPPKS Ananda Jaya. 


\section{Effect of supply chain strategy on competitive advantage}

The dissertation examination of 6 supply chain strategies on competitive advantage has a direct and significant effect by explaining the conclusions of the calculations contained in the CR results amounting to 3.070 and the probability value of 0.002 where the recorded number is lower than 0.05 , this condition proves that the supply chain strategy has an impact positive about competitive advantage, thus H-6 was approved (Nelly \& Azhar, 2016) The findings from this analysis reinforce and sharpen that with a good supply chain strategy, consumers can differentiate products based on their quality. Inadequate priority management for carrying out the goods inspection model, but more fundamentally because of UPPKS Ananda Jaya production operation to produce the best and sell well in the market.

\section{CONCLUSION}

The company's capabilities have a positive impact on competitive advantage. With adequate company capabilities, it can have a good influence on competitive advantage so that it can make UPPKS Ananda Jaya increasingly increase. Supply chain management practices that do not affect competitive advantage. Thus, good supply chain management practices carried out by UPPKS Ananda Jaya have not been able to contribute to competitive advantage. The responsiveness of the supply chain has a positive effect through competitive advantage. Thus, adequate supply chain responsiveness will have a good impact on the competitive advantage of UPPKS Ananda Jaya. Competitive advantage has a positive impact on company performance. The more competitive advantages are increasing so that the business from UPPKS Ananda Jaya is getting better. Supply chain management practices have a positive impact on company performance. The company's performance will continue to improve and improve because the management practices carried out by UPPKS Ananda Jaya are very good. The supply chain strategy has a positive impact on competitive advantage because of the right supply chain strategy so that it can increase strength in competing at UPPKS Ananda Jaya.

The company's capabilities are a collection of all the skills possessed by the company and formulate various strategies. So that it can produce a quality product and can meet customer desires. With the fulfillment of customer satisfaction, it can increase the advantages of the products produced by the company. This can also encourage the company to progress and develop. 
Supply chain management practices in the provision of goods and services are very necessary for companies because they can increase competitive advantage and have an impact on company performance. In addition, supply chain management practices are activities carried out by organizations or companies in creating an item and can promote the processing results effectively to consumers.

The responsiveness of the supply chain forms a network of companies that simultaneously work to produce a product and deliver the product into the hands of consumers. A good company must have a wide network so that it is easy to market their products. Such as distributors, shops or retail, and other forms of business, so that the results of products can be easily obtained by customers. Retail is an excellent network in supply chain management because it can communicate directly with end customers.

A supply chain strategy is needed in companies to be able to carry out company policies so that meeting consumer desire requires skills. Especially in product processing runs smoothly and guarantees to get stock of goods. With the fulfillment of stock of goods in the market to provide comfort because it can meet customer desires.

Competitive advantage is the advantage that a company has over its competitors. As the final goal to reach consumers, by offering lower yields so that the benefits are greater, this is done to keep the end consumers satisfied with the services provided by the company.

Company performance is a way of working to achieve the desired results and get value from each activity carried out. Performance is the company's ability in every performance that has an impact, therefore it must work well and maximally. Also, consider the quality obtained can meet consumer desires. The fulfillment of customer satisfaction can improve the performance of the company.

The research area is quite wide and far apart so it takes a long time to conduct research with a large number of samples, it is advisable for further research to prepare at an earlier time to obtain maximum results.

There are still invalid hypotheses so it is still necessary to research by increasing the number of samples by involving all retail distributors at UPPKS Ananda Jaya.

There are shortcomings that can become new knowledge for researchers in the future. Future researchers are expected to re-examine invalid variables such as supply chain management practices that have been stated and tested have no positive effect on competitive 
advantage, the goal is to make these variables valid. Further research is suggested to be able to add to product quality with independent variables that affect company performance through competitive advantage. So that further research can broaden the understanding of supply chain management and competitive advantage to develop company performance.

\section{REFERENCES}

Arifianti, R., Un, raharja jaja sam, \& Rivani. (2019). Implementation of Dropship Strategy Inn Supply Chain In Ceramic Industry. Pemikiran Dan Penelitian Administrasi Bisnis Dan Kewirausahaan, 4(3), 243-250.

Arsiwi, P., \& Adi, P. W. (2020). Interpretive Structural Modelling Untuk Meningkatkan Daya Saing. PASTI, 14(1), 26-36.

Brilliana, C. W., Baihaqi, I., \& Persada, fadil satria. (2020). Praktik Green Supply Chain Management. Teknik ITS, 9(1), F42-F46.

Chandra, B., Ekonomi, F., \& Internasional, U. (2021). Pengaruh koneksi politik , kinerja perusahaan dan karateristik perusahaan terhadap manajemen laba di indonesia The effect of political connection, firm performance and firm characteristic on earning management in Indonesia. Inovasi, 17(1), 35-45.

Deswati, Rismutia Hayu, et al. (2020). Pengaruh Manajemen Rantai Pasok Terhadap Performa Usaha Budidaya Udang Vaname Di Provinsi Bali Dan Jawa Timur. Sosial Ekonomi Kelauatan Dan Perikanan, 6(2), 113-124.

Jumady, Edi., Fajriah, Yana. (2020). Green Supply Chain Mnagement: Nediasi Daya Saing Dan Kinerja Perusahaan Manufaktur. Jurnal Ilmiah Teknik Industri, 8(1), 43-55.

Hariana, F. (2020). Perusahaan Terhadap Keunggulan Bersaing J \& T Express Di Kecamatan Taman Sidoarjo. IQTISHAD equity, 2(2), 92-102.

Ilmiyati, A., \& Munawaroh, M. (2016). Kompetisi Dan Kinerja Perusahaan (Studi Pada Usaha Kecil dan Menengah di Kabupaten Bantul). Jurnal Manajemen Bisnis, 7(2), 226-251.

Jumady, E. (2020). Analisis Pengaruh Manajemen Rantai Pasok Terhadap keunggulan Kompetitif Dan Kinerja Prganisasi Pada UMKM Handycraft Dan Tas Di Semarang. Jurnal Wawasan Manajemen, 2, 123-133.

Kasmari, \& Indriyaningrum, K. (2020). Supply Chain Management : Pengaruh Supply Chain Management. 978-979.

Kurniawan, R., Mangunwihardjo, S., \& Perdhana, M. S. (2018). Analisis Pengaruh Kemampuan Perusahaan, Daya Respon Rantai (Studi pada Rantai Pasok Pelumas Jawa Tengah). Jurnal Bisnis STRATEGI, 27(2), 150-166. 
Lasminiasih, Rooswhan Budhi Utomo, S. N. D. (2018). Analisis Pengaruh Permodalan, Pemasaran,Teknologi \& Inovasi, Kecerdasan Spiritual, dan Perencanaan Strategi Terhadap Kinerja Usaha Kecil Menengah (UKM) Mebel di Klaten Jawa Tengah. Bisnis Dan Manajemen, 11(1), 47-66.

Lestari, I., Astuti, M., Ridwan, H., Ekonomi, F., Pembangunan, U., \& Veteran, N. (2019). Pengaruh Inovasi Dan Orientasi Kewirausahaan Terhadap Keunggulan Bersaing UMKM Kuliner. Jurnal Riset Manajemen Dan Bisnis, 4(1), 111-118.

Lobwaer, A. K. R. (2018). strategi rantai pasokan usaha penggilangan padi kabupaten merauke. Ilmu Ekonomi Dan Sosial, 4(2), 74-80.

Maddeppungeng, A., \& Kusuma, W. M. (2019). Pengaruh Strategi Dan Praktik Supply Chain Management Terhadap Kinerja Operasional Perusahaan ( Studi Kasus : Beton Precast dan Readymix di Daerah Banten ) Jurusan Teknik Sipil Universitas Sultan Ageng Tirtayasa || Jurusan Teknik Sipil Universitas Sultan. Jurnal Fondasi, 8(2), 97-108.

Madeppungeng, A., S, D. N., \& Murtiadi, J. (2020). Pengaruh Pemicu Internal dan Pemicu Eksternal Strategi Supply Chain Management (SCM) Terhadap Perusahaan Precast. Jurnal Fondasi, 9(1), 32-43.

Mohamad, R., \& Niode, I. Y. (2020). Analisis Strategi Daya Saing (Competitive Advantage) Kopia Karanji Gorontalo. Kajian Ekonomi Dan Bisnis, 13(1).

Nelly, R., \& Azhar, A. (2016). Pengaruh Supply Chain Management Terhadap Kinerja Perusahaan Melalui Keunggulan Bersaing. Ekonomi. 12(3), 462-479.

Nurdianti, A. R., Prastawa, H., \& Budiawan, W. (2017). Analisis Pengaruh Praktik Manajemen Rantai Pasok Terhadap Keunggulan Kompetitif Dan Kinerja Organisasi Pada UMKM Handycraft Dan Tas Di Semarang. Industrial Engineering Online, 6(2), 1-11.

Nurkamil, Y., Alam, A. S., \& Nursilah, S. (2020). Pengaruh Kepercayaan Dan Komitmen Terhadap Kepuasan Supplier Beras Di Perusahaan umum Badan Urusan Logistik (Studi Kasus: Di Perum BULOG Kantor Cabang Cianjur). AGRITA (AGri), 2(2), 87. https://doi.org/10.35194/agri.v2i2.1172

Pahlevi, T. A. (2020). Kemampuan kontraktor dalam mengidentifikasi faktor pemasaran dan penawaran sebagai keunggulan daya saing di kota banda aceh. Of The Civil Engineering Student, 2(1), 57-63.

Qinthara, F., Suzan, L., \& Assalam, A. G. (2020). Pengaruh Strategi Bisnis Terhadap Kinerja Perusahaan (Studi Pada Perusahaan Sektor Industri Barang Knnsumen Yang Terdaftar Di Bursa Efek Indonesia (BEI) Tahun 2015-2017. E-Proceeding of Management, 7(2), 59705977. 
Rachmarwi, W. (2018). Praktik Manajemen Rantai Pasokan Di Industri. Manajemen Bisnis Krisnadwipayana, 6(1), 58-68.

Riany, A. I. (2020). Pengaruh Kreativitas Dan Industri Terhadap Keunggulan Bersaing (Studi Kasus Wedding Organizer Hastina Puspita Decoration Kota Jambi). Manajemen Terapan Dan Keuangan, 9(2), 94-104.

Sanjaya, C. F., Kusumawardhany, P. A., \& Rahayu, S. (2016). Praktik Manajemen Rantai Pasok Terhadap Keunggulan Bersaing Pada Minimarket. Konferensi Nasional Riset Manajemen X.

Supriyato, \& Rahmasari, L. (2020). Analisis Pengaruh Supply Chain Integration Dan Inovasi Terhadap Kinerja Perusahaan (Studi Kasus Pada Perusahaan Freight Forwading Di Semarang). Sains Tegnologi Transportasi Maritim, 2(1), 11-19.

Yun, Y., Ahmad, A., \& Nurmansyah, H. (2020). Competitive Advantage Perfume Products Affected By Value Chains Through Coordination Supply Chains Of Perfume In Cimahi City. INOVASI, 16(2), 362-372. 